Faruk M. Bajraktarević*

University of Sarajevo

Faculty of Philosophy

Department of English

\title{
SELMA DABBAGH'S OUT OF IT: INTO THE UNCHARTED TERRITORIES OF PALESTINIANNESS
}

\author{
Original scientific paper \\ UDC 821.111-31.09 Dabbagh S. \\ https://doi.org/10.18485/kkonline.2021.12.12.3
}

The paper discusses Selma Dabbagh's debut novel Out of It within the context of crisis of Palestinian resistance and political agency following the first Intifada and the Treaty of Oslo, defined not only by indiscriminate and unceasing Israeli violence but also by rampant corruption of the national leaders, Western humanitarian paternalism and consequently swelling cynicism, defeatism, distrust of dominant political narratives and apathy among the citizens of the Gaza Strip. The principal importance of the novel lies within its departure from dominant discursive tropes of representation of Palestinians and their resistance in Anglophone postcolonial studies by creating characters whose attempts to get "out of it" are read as acts of disidentification from hegemonic narratives of family, nation, martyrdom, resistance, representation and political and humanitarian activism. Such acts are - although indicative of self-interested hyperindividualism supplanting the collective grand narratives - not to be read as mere expressions of the aforementioned late-modern sentiments and inclinations but as, evidenced by the novel's key character's final act, fuzzily articulated altruistic acts of political self-sacrifice through symbolic self-deliverance and potential liberation of Palestinian political imagination by overcoming the hegemonic discursive limits of its articulation.

Keywords: agency, apathy, disidentification, late-modern subjectivity, Palestine, political self-sacrifice, resistance

The reading of Selma Dabbagh's ${ }^{1}$ debut novel Out of It (2011) in this paper extends its eponymous phrase to discuss its characters' varied attempts to escape the burdens of geography, history and hegemonic dead-end nationalist narratives in the specific context of the brutal Israeli siege of the Gaza Strip, everyday violence, ceaseless uncertainty, as well as the failure of the established narratives of Palestinian resistance and political agency. Such attempts to critically depart from established discursive structures - often in hazy directions or toward unclearly articulated alternatives - are in contemporary theories of literature and culture encapsulated in the prefix post-, which I will make use of in the paper, so J.D. Taylor's question in his Negative Capitalism: Cynicism in the Neoliberal Era summing up the unpredictability

*Filozofski fakultet Univerziteta u Sarajevu, Franje Račkog 1; e-mail: faruk.bajraktarevic@ff.unsa.ba

${ }^{1}$ Learn more about the author at https://selmadabbagh.com/ 
of the postmodern trajectory, "from post to where?" (2013), might be adapted to outline Dabbagh's concern over the moment of crisis in which the novel's main characters seek alternatives to what constitutes their individual and communal reality - "out of it, but to where?" The absence of explicit answers is, however, not read as an expression of hopelessness in face of an impassable wasteland of fake promises, wasted opportunities and unreachable goals but rather of something that Katherine Natanel in her examination of left-winger apathy among Israeli Jews addresses via Donna Haraway's notion of elsewhere as a "space of difference and diffraction, a site of interruption and interference that creates the possibility of change" (2016: 106). In the light of the elsewhere's disruptive potential by means of "renunciation of [...] master discourses" (Aronowitz, 1987: 99), my reading of Out of It recognizes Ato Quayson's suggestion of the complementary roles of postmodernism and postcolonialism in understanding the contemporary world (2000:106), or, in this case, the crisis and fragmentation of Palestinian political subjectivity and agency in a wellknown context, the public were again reminded of earlier this year. ${ }^{2}$ Starting from the view proposed by Bill Ashcroft, Gareth Griffiths and Helen Tiffin (2001) that the prefix post- should not be interpreted chronologically but, primarily, ideologically, as oppositional to colonial practice and discourse (117), including its contemporary manifestations, one could not only see postcolonialism's relevance in Palestine but also the points of its congruence and complementariness with postmodernism. Kwame Anthony Appiah thus insists that the two posts- concur in their oppositional and antiessentialist challenges to hegemonic "legitimating narratives" (2001:123). This "antihegemonic [...] orientation" of both postcolonialism and postmodernism (Quayson: 96), along with other posts, opens up a space in which to analyze the aspirations of Dabbagh's characters to get "out of it" as their needs to disidentify from and delegitimate the hegemonic narratives of family/nation, resistance, scholarly endeavors and humanitarian activism, whose primary aim is "to validate institutional subordination and silence the voice of competitors" (Quayson: 95), among whom are

2 Those events indicate, among other things, multiple fault lines of the suggested framework. While acknowledging them, the paper will neither offer impossible answers to questions and doubts pertaining to postmodernism's proscribed role in undermining the narratives of postcolonial/national emancipation (Quayson, 2000: 87; During, 2001: 125) or its appropriateness in throwing light on social, political and cultural realities outside the Euro-American framework (Ekpo in Quayson: 87) nor will it expound on the complex and open questions of the postcolonial status of Palestine (Ball, 2012; Moore, 2018). The recent repeated clashes between Hamas and Israel is just a fresh reminder that postcolonialism, understood as "a studied engagement with the experience of colonialism and its past and present effects, both at the local level of ex-colonial societies, as well as at the level of more general global developments" (Quayson, 93-94, my italics) - keeping in mind that Palestine's ex-coloniality might at best be viewed as "[a] premature celebration" (McClintock, 1992: 88) - is only a partially sufficient framework for addressing the Palestinian question. 
individuals, often "the victims of the postcolonial state" (Appiah: 123) viewing their identities within alternative, however fuzzy, frameworks from the ones defined by the Palestinian Authority and other (inter)national movements and organizations engaged in the Palestinian political process.

\section{Beyond Victims and Fighters}

Dabbagh's fictional treatment of the Palestinian question as the most graphic example of "late-modern colonial occupation" (Mbembe, 2003: 29) constitutes not only a quantitative contribution to the meager interest of Anglophone postcolonial studies in Palestine - long absent from the field (see Ball, 2012; Moore-Gilbert, 2016) - but also a qualitative departure from dominant representations of the Palestinian subjects, as either "powerless victims" or "resistant fighters" (Ball, 2012: 6) informed by principal paradigms of articulating resistance. Such paradigms faced significant challenges in the historical period Dabbagh chose to situate her novel in, i.e. the context of crisis of Palestinian political subjectivity during the so-called "Oslo era" (Allen, 2013), characterized by international pacification of Palestinian resistance, institutionalization of politics and activism, corruption and consequent desocialization, depolitization and endless fruitless disputes over forms of public engagement in the besieged and formally autonomous Palestinian territories. Just like Western postmodern cynicism, defeatism, distrust and apathy, as Chris Snipp-Walmsley insists, are impossible to understand outside the specific historical context of late 1960s and "a failure of revolutionary aims" (2006: 413-415), the crisis of Palestinian subjectivity - expressed through these postmodern sentiments - is represented in the light of postIntifada failures, disappointments and political disorientation which define the relations not only within the Mujahed family but Palestinian community in the country as well as the diaspora. The novel addresses the crisis through a wide array of characters from or related to the Mujahed family but is primarily focused on Rashid Mujahed as the novel's main embodiment of the crisis and potentially productive elsewhere-directed dissociation from the imposed stereotypes. He is portrayed as what Laura Junka-Aikio calls in her study of Palestinian postcolonial late modern politics Late Modern Palestine: The Subject and the Representation of the Second Intifada - echoing Mbembe's description of Palestine's neocolonial status - "late modern subject of colonial occupation" (2016: 16), whose ideological location is suggested by the novel's title, and could be, in Junka-Aikio's terms, described as a typical late-modern/postmodern 
${ }^{3}$ dislocatedness between "mutually incommensurable paradigms of power and subjectivity and thus inarticulable and unrepresentable in terms of either of them" (16), which accounts for the lack of clearly defined alternatives to the ones Rashid wants to get out of. Rashid's personal dislocatedness is equally evident in relation to the paradigms of understanding the Palestinian question established in the country and abroad, so his subjectivity and agency are built against the multiple restrictive claims of reality shaped by Israeli violence in the Gaza Strip, Palestinian "aesthetics of martyrdom" (Junka-Aikio: 54) as well as Western humanitarianism, reduced to sheer activist validation of preconceptions of the Palestinian subject in need. As someone who, in Edward Said's words, refuses a relationship founded on "the exploitation of [discursive] dependence" (2000: 295) on multiple levels, Rashid, as the first part of the paper shows, only seems to embody the aforementioned late-modern/postmodern self-centered sentiments, but actually - performing an act of both personal (however illusory and temporary) escape "out of it" and altruistic political self-sacrifice - matures into an epitome of much needed alternative conceptions of the Palestinian subjectivity and its reconstitution out of and away from internal and external narratives in crisis following the first Intifada and the Treaty of Oslo.

\section{The Gazan Prison between Violence, Corruption, Nostalgia and Action}

In her 2012 interview for the Gulf News, speaking about challenges of writing about the life in Gaza in Out of It, Selma Dabbagh admits that for the city of Gaza in the state of war and siege is the most representative place to think about the Palestinian political subjectivity constituted through resistance to ceaseless brutal violence. Crossing the lines of her personal experience - since, as she admits, of the three places the narrative of Out of It is situated in, she was least familiar with Gaza - Dabbagh at the same time crosses the boundaries of the "imaginative geography", according to which, as Derek Gregory argues, Palestine and its citizens are located "outside the space of Reason" and "beyond the pale of civilization" (2004: 187), represented as a permanent threat to Israel as a symbol of "human decency" (Allen, 2013) in order to paint the essence of the contemporary colonial rule, within which Palestinians, facing regular revenge attacks by Israeli bomber planes and helicopters, figure as Agamben's homines sacri, devoid not only of political subjectivity but also of

\footnotetext{
${ }^{3}$ The two are used synonimously in the paper as representative of the present moment or state of "resolution and dissolution of collective ethical frameworks and ideals (whether traditional-religious or modern-secular [depending on the context, as is evident in Dabbagh's novel], [...] [resulting in, as Dabbagh further shows] an amplified and intensified anomie and loss of meaningfulness, a moral [and political] vacuum experienced individually and collectively (Keohane et al., 2017: 2).
} 
the right to bare life. Dabbagh's Gaza - where the war is everything but a clash of equals and resembles, as Rashid describes it to his girlfriend and British activist Lisa, "a cage fight, where the other side could throw these flying kicks but their side was limbless or heavily disadvantaged in some way and kept getting disqualified for spitting" (2011: 30) - is a city turned into "a huge prison" (Gregory: 187), within which "not even buildings should be singled out for survival" (Dabbagh: 21), its homeless citizens, whose homes are levelled by Israeli bulldozers, and other citizens, victims of nerve gas attacks or movement restriction policies, not even "indulg[ed] with reasons $[\ldots] "$ " (Dabbagh: 61 ) behind the indiscriminate violence.

Dabbagh, however, portrays the life within the Gazan prison as not only shaped by that violence but by a widespread sense of disillusionment with the Palestinian authorities and the outcomes of the Oslo treaty, which, as Junka-Aikio argues and Dabbagh demonstrates in the novel, while bringing very little of what could be described as true national sovereignty, introduced "new questions, problems and transformations which are usually associated with formally independent postcolonial states and societies" (Junka-Aikio: 75), such as the political leadership focused on personal gains at the expense of wider national and communal interests (Allen, 2013). Daily experiences of dealing with the Gazan dire infrastructure are thus regularly punctuated with the citizens bumping into a Mercedes with bulletproof windows, whose passengers they spit at, yelling "Look at them! Negotiated us away in exchange for that car, did you? So you can move it up and down the one kilometre of Gaza you liberated, did you? Bravo! Bravo"(Dabbagh: 47). Such futile outbursts of anger are, as Dabbagh further shows, only symptoms of deeper social failures, political disintegration and disorientation and ideological bankruptcy of pre-Oslo nationalist narratives, all evident in the fractured Mujahed family and the familial dynamics among its members. Mr. and Mrs. Mujahed and their oldest son Sabri are representatives of the crippled Palestinian secular elite, either exiled or ignorant and at times futilely defiant of the fact that their political power and influence are waning in the face of rising Islamist organizations and parties. Sabri's thesis about his own crippledness following the attack in which his young wife Lana and newborn son lost their lives mirroring the state of the entire nation, so "Occupation, the closures, the siege have made amputees of all of us, crawling around in the mud. Legless in Gaza. The lot of us" (Dabbagh: 107) is a precise reflection on the atrophied ideology of secular resistance, reduced to "it's-for-the-good-of-the-nation" (Dabbagh: 60) platitudes recited by grieving mothers or, as Lori Allen puts it, "the political life of nostalgia" 
(2013), evident in Sabri's reminiscences of "the heady days of resistance" (Dabbagh: 82) during the first Intifada, "this era of history which he had contributed to making" (Dabbagh: 41). The present void, however, is filled by the Islamists, which gain credibility by instrumentalizing religion as, in Illan Pappe's words, "an effective response to the pressures of endless uprooting, deprivation and discrimination" (2006) and attain their strength through recruitment of girls from secular families, loyal to the Authority (The Palestinian National Authority/PNA), such as the Hajjar's daughter, whose bombing attack triggers a new wave of Israeli revenge airstrikes, Iman Mujahed, who, having returned to Gaza from Switzerland, is looking for a meaningful role that would not be the one "of wife and mother, both of which were pushed down at her constantly" (Dabbagh: 18), loses two friends in the airstrikes and realizes that it was Islamists that offer her a chance to act beyond (and out of) the idle political scene, marked by endless divisions:

Deaths of children changed everything. Resistance movements started with dead children. And there she was, for it did not matter who it was that she followed really, all this hairsplitting about what party you backed, which leader and what position that had been taken on the agreements of 1973 , '78, '94. Who cared? To hell with it. The thing was to act and that was what she was doing. Peoples Fronts, Popular Wings, United Leaderships - the hell with them, too. It was all about action, there were no alternatives (Dabbagh: 71).

\section{Your Duty Is to Yourself}

The divisions Iman is interested to overcome by action affect the family members as well, but the key division among the Mujaheds is the one of occupying different, as David Scott calls them, "problem spaces", or discursive frameworks - always with limited historic applicability - within which the notions of political subjectivity and their articulation are defined (in Junka-Aikio: 11). It is the "problem space" Iman identifies above that sets her apart from the rest of her family: her resigned mother - once a prominent PFLP (The Popular Front for the Liberation of Palestine) member, internationally wanted for hijacking a plane - now "making pickles" (Dabbagh: 71), her older brother Sabri, now only scholarly involved with the Gazan reality, "documenting destruction. Chronicling chaos. Point by strike by shot" (Dabbagh: 36) 
and trying to fathom "the roots of the divide" (Dabbagh: 121$)^{4}$, or Rashid, who "just prostrated himself before anything Western" (Dabbagh: 71) and, above all, their exiled and estranged absentee father, Jibril Mujahed, a former member of the PLO, who now lives in an unnamed Gulf country, thankful to "the glittering forest of duty-free shops around him" for being "out of it" (Dabbagh: 161), insensitive to what Iman views as still burning issues of Palestinian resistance, such as boycotting of American coffee franchises and focused instead on tabloid articles about adultery or sexual mischiefs, for "un-Islamic behavior tickled him to the core" (Dabbagh: 158). The divide between the "problem spaces" is apparent in the airport and Jibril's new home, Dabbagh presents as meeting points of varying experiences that constitute the Palestinian "unifying national destiny" (Dabbagh. 163). Thus Iman, a typical Palestinian homo sacer, kept and questioned for more than ten hours at the Gaza Strip's border with Egypt, encounters a number of "uprooted bodies" (Hanafi, 2009: 118), which - unlike the ones Hanafi warns about, which are difficult to control, ready to explode, hijack or attack - epitomize the late-modern "widespread cynicism and political passivity" (Junka-Aikio: 32) and unwillingness to assume the burden of participation in social processes (Taylor, 2013). Among them is Jibril, who lectures Iman about collective suffering, while wearing a t-shirt with Ferrari's "prancing horse" (Dabbagh: 170) or Salem Abu Wazir, a young man working as a waiter for the Starbright coffee franchise under the alias Ernesto, because "market research has found that Spanish names are more amenable to the clientele" (Dabbagh: 176) or Jibril's partner Suzi, whose experience of growing up in refugee camps with faded hopes for the return taught her that "Your duty is to yourself" (Dabbagh: 176). Apparent in Suzi's story is what Katherine Natanel describes as the seemingly endless cycle of "emotions of fear, aspiration, and fatigue" in which the individual's will for political or activist engagement in social processes wears away and new desires for the ideal of "effortless living" are created (Natanel, 2016: 39). Dany-Robert Dufour describes such desires as typical late-modern "ego-oriented" narratives, supplanting "grand collective" ones, and focused on pursuing small egotistical interests as "the cure to all [in this case Palestinian] ills" (2017: 15). Similar desires are expressed among the disillusioned

${ }^{4}$ Organized in five parts and distributed among three locations (Gaza, the Gulf and London) and over periods of time, the narrative of Out of It never provides precise dates, so it is impossible to know exactly what particular events are referred to. Events like Sabri's divide can have multiple references - which probably underscores their paradigmatic character within the Palestinian political experience - so the divide here might be interpreted as either the one between Hamas and Fatah from 2006 or, more probably, the one from 1993, when following the Oslo Accords, Arafat's PLO was opposed by radical nationalist and militant fractions from the organization, such as PFLP (Popular Front for the Liberation of Palestine) or Hamas and Islamic Jihad (see Shlaim, 2005). 
Gazan citizens, so Rashid's friend and partner from the Human Rights Documentation Centre in Gaza, Khalil Helou - convinced in the importance of his work, for "[0]therwise they've won" (Dabbagh: 59) and viewing Rashid's departure to London as "no less than treacherous, no more than self-interest - faces criticism from his own mother, who argues that his activism is "for nothing" (Dabbagh: 77) and that he should join Rashid in London and, finally "go out. Have some fun" (Dabbagh: 77). 5 Rashid's trajectory is, like Iman's and Khalil's, "apart from the rest of his family" (Dabbagh:201), but unlike theirs - and like Jibril's or Suzi's - it is not, at this point at least, directed towards alternative collectivist goals of action or humanitarian empathy but towards pleasing his own wishes, thus becoming another typical late-modern subject, unwilling, in Dufour's words, "to create for itself [or, better, accept already created] sufficiently broad spatial and temporal coordinates" (16). Instead of pursuing activist goals or dealing with questions pertaining to familial or national history, Rashid lives in a state of "depressive hedonia" (Fisher, 2009: 21), subjected to the "imperative to enjoy" (Fisher, 2009: 71) in Gloria, his marijuana plant helping him to truly get out of it and enjoy in "his reality to the exclusion of all else" (Dabbagh: 28), as well as his dreams about leaving for London - a somatic manifestation of his non-belonging (Natanel: 60) - where he ends up on scholarship, never viewing the city as a place for his academic pursuits but one for "effortless living" (Natanel, 39) out of it. Thus in random ordinary conversations among Londoners - which Iman experiences as an "enviable ability to relinquish involvement in the bigger picture (Dabbagh: 185) and a confirmation of Western "complicit[y] with each missile that blasted [Gaza], each sheet-wrapped body thrown into a mass grave, each child screaming outside a demolished home" (Dabbagh: 186) - Rashid sees as a tide of promises that he would finally be able to live the wanted life in what is primarily - as is the case with his father's life in the Gulf - an ego-satisfying "elsewhere" (Natanel: 106) "[o]ut of the whole damn shit" (Dabbagh: 248):

On that first night, the street had been rich with promises for his future in London. These were bars and cafés that were waiting for him. They were places were Rashid would be known. There would be a cheer from the tables as he entered. His

5 Lori Allen, however, identifies a concurrence between the post-Oslo rise of human rights industry, perceived as a form of soft colonialism, and the weakening of nationalist narratives of resistance. Funding of human rights organizations - conditioned on meeting established criteria of Western donors, addressed by Dabbagh through the relationship between Rashid and Lisa - depolitization, professionalization and institutionalization of politics and activism, led to, as Allen notes, a rise in cynical distrust among the Palestinians of everything this industry represents to them, so it might be viewed as yet another contributing factor to the growing political apathy - tripled in the period 1994 - 1999 - colloquially encapsulated in the phrase suffayt wa tuffayt (I parked and turned off the engine). 
friends would pull him into discussions, jokes would be told, and they might even cajole him into playing instruments that he would discover an untapped talent for. He would be known. He would be loved. He would be free (Dabbagh: 132).

\section{Affording the Luxury to Disidentify}

Still, Rashid's ego-oriented narrative is not reduced to "dejected apathy" (Fisher: 30), a complete lack of interest in broader issues pertaining to the Palestinian question or postmodern cynicism as a symptom of "conservative inaction and truce with the state of things" (Taylor, 2013). Rashid's "disidentification from the control program[s]" (Fisher: 30) imposed on him by his family or Western interlocutors like Lisa or Professor Myers is accompanied by numerous "acts of knowing, caring, seeing, feeling and doing" (Natanel: 7), so although he is "fed up and cynical" (Dabbagh: 30), he works with Khalil on gathering evidence about human rights violations in Gaza, consumes the news, talks Iman into attending the protest rally organized by Lisa, and feels rage "at the top of his skin running down his arms [...] he could barely control" (Dabbagh: 141), while speaking about the corrupt leaders of resistance in Gaza. On that account, his attitude should be understood along the lines of Lori Allen's discussion of political cynicism in the Palestinian context - not a dejected acceptance of "the political stasis" but an unclearly articulated/unarticulated "critique and search, or at least hope, for something better" (Allen, 2013). That dim alternative stands against the problem-spaces imposed on him by his older family members, reminding him, like Sabri does, "that he could never relax, never be part of anything or anywhere unless it was part of a push for change, for resolution" (Dabbagh: 120) or, on the other side, Professor Myers and Lisa, whose respective academic/intellectual and humanitarian/activist interests in Palestine are shaped in the shadow of the British colonial presence in Palestine or, as Michael Barnett (2013) writes, the Western humanitarian paternalism with its apparent disbalance between the giver and the receiver (Skinner and Lester, 2012: 740). Both of the latter relationships are presented as acts of (neo)imperial epistemic exploitation of the other. Rashid, as the Palestinian other, in both cases is not projected as an active interlocutor but a passive receiver and validator. Thus Professor Myers - who never managed to explain why he chose Palestinians as subjects of his academic interest, among so many other "destitute and abandoned people" (Dabbagh: 127), still retains vivid memories of his service in Palestine, where he, as a young police officer, participated in hanging an innocent villager, an atrocious act that was, as he concludes, "all justified under the Emergency 
Laws of His Majesty's Government in Palestine, the same laws that are now being used for closures, house-sealings, curfews, demolitions and the rest of it. All British, those laws" (Dabbagh: 129) - after reading a draft of Rashid's master's thesis, highlights and energetically approves the passage Rashid plagiarizes from Sabri's e-mail message. In the same manner Lisa attempts to shape Rashid as someone who duly delivers what she is after in her advocacy for the Palestinian cause before the British government bodies or gratefully receives her activist benevolence. Therefore, it does not surprise that Rashid disappoints whenever he fails to deliver, as he does during the meeting with Lisa's friend Charles Denham from the British Foreign Office, when, speaking of "druggy parties in Gaza" (Dabbagh: 142), he ruins the image not only of the chosen partner for the new peace initiative but Palestinians as a whole, misrepresenting them, Lisa insists, as "a bunch of jokers, sell-outs, hypocrites, potheads" instead of confirming an already formed image of stereotypical victims in need of humanitarian salvation from "the suffering, the bombing, the arrests, the targeted assassinations, the whole damn Occupation and its economic devastation. Not to mention the destitution or the enforced malnutrition" (Dabbagh: 143). Just as he, in Lisa's words, "can't afford the luxury of showing that off" (Dabbagh: 143), Rashid is not allowed to play a role distinct from the one chosen for him of "the brown and the destitute - victim typ[e] [and] politically repressed" (Dabbagh: 248), so one is not surprised by Lisa's glaring frustration after he gets arrested in London "just for some minor dope charge" instead of the habitual detention of the brown and destitute "for some terrorism offence or something" (Dabbagh: 247).

\section{(In Place of) Conclusion: From Selfish Presentism to Selfless Sacrifice}

This is why Rashid's final act of getting out of it, upon his return to Gaza, after the arrest and deportation, should not be viewed as an expression of selfish disinterest in broader political and social issues. On the contrary, the act of self-deliverance is at the same time one of political self-sacrifice with the aim of making "a transfer of the vitality of life" (Fierke, 2013: 49) onto those who, unlike him, possess a clearer vision of the alternative to the political stasis atrophying Palestinian agency. Unlike the morally and ethically questionable act of physical suicide or equally questionable and - in the context addressed at the beginning of the paper - clichéd act of suicide bombing attack against an enemy, when, as Sabri observes the Gazan mayhem, "we can't even remember who the enemy is any more" (Dabbagh: 280), Rashid's escape is portrayed as an altruistic deed of giving the name and identity to Ziyyad Ayyoubi - 
Sabri's revenger, a hero of resistance who lost his parents during a series of political assassinations of intellectuals in the 1970 s and $80 \mathrm{~s}$, a man with a vision of saving Palestine from its corrupt elite, which is why he is targeted by Israel and the elite - a young man who physically resembles him but is, unlike Rashid, heroically committed to the Palestinian cause. By receiving Rashid's gift of identity, Ziyyad gets a chance to "[go] away, [come] back and [save] Palestine" (Dabbagh: 300) and thus becomes to Rashid's mother "[t]he son [she] never had" (Dabbagh: 286). Rashid's escape out of it could thus be interpreted, following Stuart J. Murray, as an tanathopolitical ambivalent act of resistance (2006: 195), which is - although nondestructive of biological lives of those involved, including Rashid, as would be the case with (suicide) bombing - an act of destruction of "multiple regimes of power" within and without Palestine (Junka-Aikio: 49), an individual like Rashid escapes and negates only by means of (symbolic) death or self-initiated rejection of political and social molds one was to fit in, as well as an act of production by means of transforming an apathetic, selfish and aimless life "fixed in [...] presentism" (Dufour: 16) into an ethical life oriented towards a future of collective deliverance. This is why, in the moment of decision to leave his passport with a Canadian immigration visa to Ziyyad and taking Ziyyad's documents to plant them in a car-bomb made to finish the job of Ziyyad's assassination, Rashid finally feels "above it all. Wired with purpose. Reborn" (Dabbagh: 290). His symbolic death is thus, as Mbembe puts it, "far from being an encounter with a limit, boundary, or barrier, it is [...] a 'release' [...]" (Mbembe, 2003: 39), which could be described in Hamid Dabashi's (now dated) words of celebration of the Arab spring as a historical moment of new birth of "liberation geography" or "the opening up of hitherto unknown horizons of [Rashid's or Palestine's] world" (2012). In the novel's final chapter we meet an inspired individual who is truly "out of it", liberated from his name, status, geography and reality, "his heart propelling him forwards with a love of chance, of risk, of the opportunities for tomorrow [...] flying high above it all, up, over, out of it all; flying all the way until he reaches the sea" (Dabbagh: 308), ready, like Dabbashi's revolutionary subject, "to navigate uncharted [...] territories" (2012). In this act of Rashid's body becomes another instance of what Hanafi calls "the deracinated body [...] without a relationship to territory [...] a body in orbit, a satellite" (118) and, as such, a potential epitome of liberation of Palestinian "political and moral imagination" from dominant dead-end narratives (Falk, 2013: 85). That body is, as Hanafi further insists, in need of new forms of control and guidance, without which it threatens to become another instance of destructive subjects of nonselective terrorist 
violence (118), lacking, as Falk writes, "ethical compasses by which to guide their judgments and behavior" (79), as was the case with the Hajjar girl and almost with Iman, and thus destructive of the Palestinian sumud and the legitimacy of Palestinian resistance as values which, regardless of the bankruptcy of existing political narratives, lack of clear alternatives, corruption of current representatives of Palestinian political subjectivity or apathy of its direct or indirect agents, should not be called into question.

\section{Bibliography}

Allen, L. (2013). The Rise and Fall of Human Rights: Cynicism and Politics in Occupied Palestine. Stanford: Stanford University Press. E-book.

Ali, S.H. (2012). No Borders for Fiction Writers (an interview with Salma Dabbagh). Gulf News. Retreived from https://gulfnews.com/entertainment/books/noborders-for-fiction-writers-1.970338

Appiah, K. A. (2001). The Postcolonial and the Postmodern. In Ashcroft, B., Griffiths, G., Tiffin, H. (eds.). The Post-Colonial Studies Reader. (pp. 119-124). London: Routledge.

Aronowitz, S. (1987). Postmodernism and Politics. Social Text, No. 18, 99-115.

Ashcroft, B., Griffiths, G., Tiffin, H. (eds.). (2001). The Post-Colonial Studies Reader. London: Routledge.

Ball, A. (2012). Palestinian Literature and Film in Postcolonial Feminist Perspective. New York: Routledge.

Barnett, M. (2013). Empire of Humanity: A History of Humanitarianism. Ithaca: Cornell University Press. E-book.

Dabashi, H. (2012). The Arab Spring: The End of Postcolonialism. London: Zed Books. E-book.

Dabbagh, S. (2011). Out of It. London: Bloomsbury.

Dufour, D.R. (2017). Modern Subjectivity/Post-Modern Subjectivity. In Kieran Keohane, Anders Petersen and Bert van den Bergh (eds.), Late Modern Subjectivity and Its Discontents. (pp. 8-23). Oxon, OX: Routledge.

During, S. (2001). Postmodernism or Post-colonialism Today. In Ashcroft, B., Griffiths, G., Tiffin, H. (eds.). The Post-Colonial Studies Reader. (pp. 125-129). London: Routledge. 
Falk, R. (2013). Rethinking the Palestinian Future. Journal of Palestine Studies, XLII (4), 73-86. DOI: jps.2013.XLII.4.73

Fierke, K. M. (2013). Political Self- Sacrifice: Agency, Body and Emotion in International Relations. Cambridge: Cambridge University Press.

Fisher, M. (2009). Capitalist Realism: Is There No Alternative?. Winchester, UK: Zero Books.

Gregory, D. (2004). Palestine and the "War on Terror". Comparative Studies of South Asia, Africa and the Middle East, 24 (1), 183-195.

Hanafi, S. (2009). Spacio-cide: colonial politics, invisibility and rezoning in Palestinian territory.Contemporary Arab Affairs, 2 (1), 106-121. DOI: $10.1080 / 17550910802622645$

Junka-Aikio, L. (2016). Late Modern Palestine: The Subject and Representation of the Second Intifada. London: Routledge.

Keohane, K. Petersen, A. and Van den Bergh, B. (eds.), Late Modern Subjectivity and Its Discontents. Oxon, OX: Routledge.

Mbembe, A. (2003). Necropolitics. Public Culture 15 (1), 11- 40.

McClintock, A. (1992). The Angel of Progress: Pitfalls of the Term "Post-Colonialism" .Social Text, 31/32, 84-98.

Moore, L. (2018). Narrating Postcolonial Arab Nations: Egypt, Algeria, Lebanon, Palestine. New York: Routledge.

Moore-Gilbert, B. (2016). Palestine, Postcolonialism and Pessoptimism. Interventions: International Journal of Postcolonial Studies, 1-35. DOI: 10.1080/1369801X.2016.1156555

Murray, S. J. (2006). Thanatopolitics: On the Use of Death for Mobilizing Political Life. Polygraphy, No. 16, 191-215.

Natanel, K. (2016). Sustaining Conflict: Apathy and Domination in Israel-Palestine. Oakland: University of California Press.

Pappe, I. (2006). A History of Modern Palestine. Cambridge: Cambridge University Press. E-book.

Quayson, A. (2000). Postcolonialism and Postmodernism. In Henry Shwarz and Sangeeta Ray (eds.), A Companion to Postcolonial Studies. (pp. 87-111). Malden, MA: Blackwell Publishing.

Said, E. (2000). Reflections on Exile and Other Essays. Cambridge, MA: Harvard University Press. 
Selma Dabbagh - British Palestinian Writer and Author of Novels. (n.d.). Retrieved November 15, 2021, from https://selmadabbagh.com/

Shlaim, A. (2005). The Rise and Fall of the Oslo Peace Process. In Louise Fawcett (ed.). International Relations of the Middle East. (pp. 241-261). Oxford: Oxford University Press.

Retreived from https://users.ox.ac.uk/ ssfc0005/The\%20Rise \%20and\%20Fall\%20of\%20the\% 200slo\%20Peace\%20Process.html

Skinner, R., \& Lester, A. (2012). Humanitarianism and Empire: New Research Agendas. The Journal of Imperial and Commonwealth History, 40 (5), 729-747.

Taylor, J.D. (2013). Negative Capitalism: Cynicism in the Neoliberal Era. Winchester, UK: Zero Books. E-book.

Walmsley, C.S. (2006). Postmodernism. In Patricia Waugh (ed.), Literary Theory and Criticism. (pp. 405-426). Oxford: Oxford University Press. 